\title{
Effect of method of conservation of timothy on endogenous nitrogen flows in lactating dairy cows
}

\author{
D. R. Ouellet, ${ }^{* 1}$ R. Berthiaume, ${ }^{*}$ G. Holtrop,† G. E. Lobley, $\ddagger$ R. Martineau, ${ }^{*}$ and H. Lapierre* \\ ${ }^{*}$ Dairy and Swine Research and Development Centre, Agriculture and Agri-Food Canada, STN Lennoxville, Sherbrooke, Quebec, \\ Canada J1M 1 Z3 \\ †Biomathematics and Statistics Scotland (BioSS), Rowett Institute of Nutrition and Health, University of Aberdeen, Bucksburn, Aberdeen, \\ AB21 9SB, United Kingdom \\ $\ddagger$ Rowett Institute of Nutrition and Health (RINH), University of Aberdeen, Aberdeen, AB21 9SB, United Kingdom
}

\section{ABSTRACT}

The effect of the method of conservation of forage on endogenous $\mathrm{N}(\mathrm{EN})$ secretion was studied using a ${ }^{15} \mathrm{~N}$ isotope dilution technique in 4 lactating Holstein cows selected from a replicated $3 \times 3$ Latin square. Cows were equipped with ruminal, duodenal $(\mathrm{n}=4)$, and ileal $(\mathrm{n}=2)$ cannulas. Diets comprised $44 \%$ concentrate plus first-cut timothy conserved either as hay or as restrictively (formic) or extensively (inoc) fermented silage. Crude protein contents of hay, formic, and inoc averaged $10.4,13.6$, and $14.8 \%$, respectively. Total EN flow and free EN at the duodenum were increased with hay compared with silages but were similar when expressed as proportion of duodenal $\mathrm{N}$ flow, with total EN flow averaging 25.8, 23.9, and $23.9 \%$ for hay, formic, and inoc, respectively, and free EN at the duodenum averaging 11.5, 9.8, and 9.7\% for hay, formic, and inoc, respectively. Flow of bacterial $\mathrm{N}$ at the duodenum originating from an endogenous source tended to be higher with inoc compared with formic. Overall, the proportion of bacterial $\mathrm{N}$ derived from endogenous sources and urea was similar between treatments, averaging 23 and $15 \%$, respectively. In the feces, flow of EN was similar across treatments and averaged $31 \%$ of total fecal N. More than $70 \%$ of fecal EN originated from undigested secretions into the forestomach. Absorption of $\mathrm{N}$ from the forestomach tended to increase for silages compared with hay. In conclusion, EN represented an important fraction of $\mathrm{N}$ flowing at the duodenum and in the feces. The free EN and the total EN at the duodenum were altered by the different methods of forage conservation studied. Estimation of true dietary N supply and requirements of the dairy cow should allow for endogenous $\mathrm{N}$ flows and losses.

Key words: endogenous nitrogen, dairy cow, forage conservation, stable isotope

Received January 21, 2010.

Accepted May 6, 2010.

${ }^{1}$ Corresponding author: Daniel.Ouellet@agr.gc.ca

\section{INTRODUCTION}

Three major sources contribute to the $\mathrm{N}$ flow at the duodenum: microbial CP (MCP), RUP, and endogenous N (EN) secretions (NRC, 2001). Endogenous N flow has important implications for $\mathrm{N}$ transactions in animals because this involves recycling of anabolic N, such as AA N, between the body tissues and the gut lumen and does not make a net addition to $\mathrm{N}$ supply to the animal (Larsen et al., 2000; Sandek et al., 2001). In contrast, other sources of $\mathrm{N}$ normally considered as end products of host metabolism, such as urea, if reutilized within the gut lumen, would be considered a potential gain (Lapierre and Lobley, 2001). Often, these different sources and fates of $\mathrm{N}$ are not clearly resolved by the techniques usually employed to quantify the so-called EN secretions. Although it is recognized that EN at the duodenum needs to be quantified (NRC, 2001; INRAtion, 2004), most of the published data partition duodenal protein flow only between MCP and RUP, the latter obtained by difference between duodenal protein flow and MCP. Inevitably this will overestimate the true protein supply from undegraded feed protein. Also, the scarcity of data on EN in ruminants has constrained models to use fixed factors (e.g., based on DMI: NRC, 2001) to estimate for EN flows, failing to account for differences that may occur because of the nature of the ration, as acknowledged in pig nutrition (Jansman et al., 2002). Currently, stable isotope dilution techniques are the best approaches; with these, it was estimated that in dairy cows the EN contribution, excluding urea, could represent as much as $15 \%$ of the duodenal flow, with this partitioned between free EN and EN incorporated into MCP (Ouellet et al., 2002).

The form in which the forage is stored and fed directly affects the flow of $\mathrm{N}$ at the duodenum (McDonald et al., 1991). For example, conservation either as hay or as silages treated with formic acid or inoculated with lactic acid bacteria affects the distribution of $\mathrm{N}$ within the forage (NRC, 2001) and leads to altered total $\mathrm{N}$ flow at the duodenum (Martineau et al., 2007). In hay, 
NPN represents approximately $40 \%$ of total $\mathrm{N}$ and remains mostly unchanged during storage. Addition of inoculants of homofermentative lactic acid bacteria to silage results in greater fermentation and proteolysis with more ammonia $\mathrm{N}$ release than when fermentation is restricted with formic acid treatment, which reduces the proportion of NPN, ammonia, and free AA released in silage and thereby limits $\mathrm{N}$ degradation in the rumen (McDonald et al., 1991; Nagel and Broderick, 1992; Martineau et al., 2006). In addition, the preservation of water-soluble carbohydrates is an important feature of both hay and restrictively fermented silages as opposed to extensively fermented silages, where they are fermented to lactic acid and VFA (McDonald et al., 1991). All of these characteristics related to forage conservation have the potential to affect rumen environment and, consequently, urea recycling, bacteria synthesis, and EN movement. In addition, the particles length of the forage can also increase cell sloughing (Greenwood et al., 1997; Sandek et al., 2001) and therefore increase the contribution of cells and enzyme secretions to duodenal flow (Ørskov et al., 1986; Swanson et al., 2004).

Because sources of $\mathrm{N}$ and energy in the rumen directly affect duodenal $\mathrm{N}$ flow and because the abrasive action of the digesta can affect cell desquamation (Kennedy and Milligan, 1980; Sandek et al., 2001), we hypothesized that the mode of conservation of the forage will alter EN flows at the duodenum and ileum and in the feces. Therefore, the current study examined how EN varied when timothy, contributing more than $50 \%$ of the ration, was harvested as hay, restrictively fermented silage, or extensively fermented silage. This is part of a larger study designed to understand the complex interplays between $\mathrm{N}$ sources (including diet, recycled urea, and $\mathrm{EN}$ ) within the digestive tract and their effect on true availability of $\mathrm{N}$ to the cow (Martineau et al., 2006, 2007).

\section{MATERIALS AND METHODS}

\section{Forage Production, Cows, and Diets}

The experimental conditions met the guidelines of the Canadian Council on Animal Care (1993) and were approved by the Animal Care Committee of the Dairy and Swine Research and Development Centre (Sherbrooke, Quebec, Canada).

A more exhaustive description of the procedures used in the present experiment was published previously (Martineau et al., 2007). Briefly, 3 forages were prepared from the same timothy (Phleum pratense L.) sward. The first forage was conserved as small rectangular bales of hay, the second was conserved as restrictively fermented silage (referred to as formic; $85 \%$ formic acid at a rate of $6 \mathrm{~L} / \mathrm{t}$ of fresh forage), and the third forage was an extensively fermented silage (referred to as inoc; Lactobacillus plantarum LPH-1 and Pediococcus cerevisiae PCH-3 at final application rate of $1.25 \times 10^{5}$ $\mathrm{cfu} / \mathrm{g}$ of fresh forage).

Six Holstein primiparous lactating cows had been surgically fitted with both ruminal and duodenal cannulas (closed T-shaped, 10 to $15 \mathrm{~cm}$ distal to the pylorus) and used in a replicated $3 \times 3$ Latin square with 35-d periods (Martineau et al., 2007). Two cows were also fitted with open- $T$ ileal cannulas. Each of the 3 forage forms provided $56 \%$ of DM and was supplemented with a concentrate containing, on a DM basis, $76 \%$ ground shelled corn, $13 \%$ soybean meal, $5 \%$ calcium salt of fatty acids (Megalac, Church and Dwight Co. Inc., Princeton, NJ), and $6 \%$ mineral and vitamin premix (Martineau et al., 2007). Chromium sesquioxide $\left(\mathrm{Cr}_{2} \mathrm{O}_{3}\right)$, used as indigestible marker, was mixed with the concentrate before pelleting to provide a daily intake of approximately $15 \mathrm{~g}$ of $\mathrm{Cr}_{2} \mathrm{O}_{3} /$ cow. Rations containing $12.5,14.6$, and $15.2 \% \mathrm{CP}$ for hay, formic, and inoc, respectively, were offered at $95 \%$ of ad libitum DMI determined during the first week of period 1 . All diets were fed as TMR and distributed every other hour in 12 equal meals daily (Ankom Technology, Fairport, NY). The hay was coarsely chopped to facilitate delivery through the automated feeders. To prevent ruminal disturbance, in both the formic and inoc diets $1 \mathrm{~kg}$ (as-fed basis) of unchopped hay was offered daily. Dry matter content of silages was estimated weekly to deliver constant DM throughout the experiment (DMI $=17.5 \mathrm{~kg} / \mathrm{d} ; \mathrm{SD} 2.7)$. Amount of feed offered and orts, when present, were recorded daily. Samples of TMR, feed ingredients, and orts were sampled daily and kept frozen at $-20^{\circ} \mathrm{C}$ before being combined by period for further analyses. Animals were housed in individual tie stalls equipped with rubber mats and had free access to water. Cows were milked twice daily, at 0700 and 1900 $\mathrm{h}$, and the production was recorded. Live weight was recorded at the beginning and end of each period.

\section{Data and Sample Collection}

The first $16 \mathrm{~d}$ of each period were allowed for adaptation to the diet. Total collection of feces and urine was performed from d 16 to 22 using the methodology previously reported (Martineau et al., 2007). Representative daily samples were pooled across days by animal and period before analysis for DM, N, and urinary purine derivatives. Urea kinetics were determined between $\mathrm{d}$ 18 and 22 on the 6 cows (Martineau et al., 2007). Polyvinyl catheters were inserted into 1 jugular vein on d 18 . On d 19, cows were infused $(0.5 \mathrm{mmol} / \mathrm{h})$ in the jugular vein with $\left[{ }^{15} \mathrm{~N}_{2}\right]$ urea (98\% purity, Cambridge Isotope 
Laboratories Inc., Andover, MA) for 72 h. Duodenal digesta, fecal grab samples, and spot samples of urine were collected at 0900 and $1000 \mathrm{~h}$ on d 18 (natural abundance) and on $\mathrm{d} 22$. Because of the prohibitive cost of stable isotopes, only 4 cows (mean $\pm \mathrm{SD} ; 623 \pm$ $63 \mathrm{~kg}$ of BW; $104 \pm 28 \mathrm{DIM}$ ) were selected to evaluate EN flows. From d 27 to 35, L- $\left[{ }^{15} \mathrm{~N}\right]$ leucine (99 atom $\%$; ACP, Montreal, Canada) was infused continuously $(0.45 \mathrm{mmol} / \mathrm{h})$ in these 4 cows with peristaltic pumps (Masterflex pump, model 7523-30, Cole Parmer Instrument Co., Niles, IL) into one of the jugular veins to label and estimate EN secretions. Samples of ruminal and intestinal mucosa, duodenal and ileal digesta, feces, and urine were taken at $0900,1100,1300$, and $1500 \mathrm{~h}$ on d 34 and at $0800,1000,1200$, and $1400 \mathrm{~h}$ on d 35 . Endometrial forceps were used for the ruminal mucosa biopsy (approximately $10 \mathrm{mg}$ ) and an optical fiber endoscope (Olympus CF type P10L, Olympus Co. Ltd., Tokyo, Japan) was introduced approximately 20 to 30 $\mathrm{cm}$ distally from the opening of the duodenal cannula for the intestinal mucosa biopsy (3 to 5 subsamples, each of approximately $0.5 \mathrm{mg}$ on wet weight basis). The samples collected were immediately rinsed with saline $(0.9 \% \mathrm{NaCl})$ and frozen at $-20^{\circ} \mathrm{C}$ until further analysis. To preserve bacterial integrity during storage, duodenal and ileal subsamples were formolized $(300 \mathrm{~mL}$ plus 75 $\mathrm{mL}$ of formol physiological saline solution) whereas fecal subsamples were diluted ( $25 \mathrm{~g}$ plus $140 \mathrm{~mL}$ of distilled water) before $40 \mathrm{~mL}$ of formol physiological saline solution was added. Urine $(100 \mathrm{~mL})$ was preserved with 2 $\mathrm{mL}$ of sulfuric acid $(50 \% \mathrm{vol} / \mathrm{vol})$ and frozen at $-20^{\circ} \mathrm{C}$ until chemical determination. Duodenal and ileal bacterial pellets were prepared from approximately $100 \mathrm{~g}$ of thawed formolized digesta for each hourly sample by adapting the method described by Legay-Carmier and Bauchart (1989). Briefly, each sample was homogenized in $300 \mathrm{~mL}$ of $\mathrm{NaCl} 0.9 \%$ for $2 \mathrm{~min}$, then the homogenate was allowed to soak for $3 \mathrm{~h}$ at $4^{\circ} \mathrm{C}$ before being stomached for $5 \mathrm{~min}$ and subsequently filtrated on a $0.25-\mathrm{mm}$ sieve. The filtrate was centrifuged at $800 \times$ $g$ for $10 \mathrm{~min}$ at $4^{\circ} \mathrm{C}$. The supernatant was centrifuged twice at $800 \times g$ for $10 \mathrm{~min}$ and then the resulting supernatant was centrifuged at $9,900 \times g$ for $20 \mathrm{~min}$ at $4^{\circ} \mathrm{C}$. The pellet was washed with $300 \mathrm{~mL}$ of sterile saline followed by centrifugation $(9,900 \times g$ for $20 \mathrm{~min}$ at $4^{\circ} \mathrm{C}$ ). This washing was repeated once. The bacteria pellet was resuspended in $50 \mathrm{~mL}$ of sterile water, frozen at $-20^{\circ} \mathrm{C}$, and freeze-dried.

\section{Chemical Analyses}

Urea Kinetics. The ${ }^{15} \mathrm{~N}$-urea isotopomers from urine were prepared and analyzed as described by Sarraseca et al. (1998). Urinary urea $\mathrm{N}$ excretion was esti- mated from urinary volume collected on d 22 and urea concentration from a pooled sample from d 19 to 22 . For bacteria isolation, approximately $100 \mathrm{~g}$ of thawed formolized duodenal digesta from each sample was prepared as described previously. The ${ }^{15} \mathrm{~N}$ enrichment of bacteria was determined as described below. The rumen fluid was strained through 4 layers of cheesecloth and centrifuged at $20,000 \times g$ for $15 \mathrm{~min}$. Ten milliliters of the supernatant mixed with $10 \mathrm{~mL}$ of saturated sodium tetraborate as the alkaline reagent were steam distilled using a Kjeltec apparatus (Tecator 1030) modified to allow collection of the distillate. Distillates were trapped using $15 \mathrm{~mL}$ of $0.05 \mathrm{~N} \mathrm{H}_{2} \mathrm{SO}_{4}$ and dried. The dried ammonium salt and bacteria were analyzed for ${ }^{15} \mathrm{~N}$ isotopic enrichment (IE) using a Europa 20:20 continuous-flow isotope ratio mass spectrometer (Europa Scientific, Crewe, UK) interfaced to a Roboprep CN elemental analyzer (Europa Scientific).

Endogenous $\boldsymbol{N}$ Secretions. The total N content of feed and orts samples was determined by thermal conductivity (Leco model FP-428 Nitrogen Determinator, Leco, St. Joseph, MI). The concentration of N in acidified urine samples was determined by microKjeldahl analysis (method 955.04; AOAC, 1990). Fecal and digesta samples collected on d 34 and 35 were freeze dried, ground through a 1-mm screen Wiley mill (Arthur H. Thomas, Philadelphia, PA), and analyzed for analytical $\mathrm{DM}\left(135^{\circ} \mathrm{C}\right.$ forced-air oven for $2 \mathrm{~h}$ for digesta samples or $70^{\circ} \mathrm{C}$ vacuum oven for $12 \mathrm{~h}$ for fecal samples). Ruminal and duodenal biopsies were freeze dried and homogenized with a mortar and pestle. For each animal, processed samples from the 2 morning collections were pooled, as were the samples from the 2 afternoon collections, to produce morning and afternoon composite samples $(\mathrm{n}=4)$ to determine IE using an elemental analyzer (Carlo Erba Strumentazione NA 1500, Milan, Italy) coupled to an isotope ratio mass spectrometer (SIRA 12, VG Isogas, Middlewich, UK). Chromium in the pooled fecal samples collected during the $\mathrm{N}$ balance and in daily pools of feces and digesta collected on d 34 and 35 was measured by atomic absorption with an air-acetylene flame (Siddons et al., 1985).

\section{Calculations}

Urea kinetics were estimated using the model developed by Lobley et al. (2000). The EN secretions were calculated as presented in Ouellet et al. (2002), except that the proportion of duodenal bacteria originating from urea recycled to the rumen was directly estimated by the ratio of the IE (atom \% excess) of bacterial $\mathrm{N}$ to urinary urea $\mathrm{N}$ from samples collected on $\mathrm{d} 22$ at the end of the labeled urea infusion. Similarly, the 
proportion of bacteria $\mathrm{N}$ originating from ruminal ammonia was determined using ${ }^{15} \mathrm{~N}$ IE (atom \% excess) of the ammonia in the rumen fluid over that of total bacteria $\mathrm{N}$, also on samples collected on d 22 of each of the 3 periods. For the EN secretion flow at the ileum, the calculations were identical to calculations in the feces, except that the ending point was the ileal digesta rather than the feces. Based on the biopsies taken during d 34 and 35 of each period, the calculated EN is presented using 2 possible precursor pools: mucosa and combined. For mucosa, the IE of the rumen biopsy for the forestomach compartment and the IE of the intestinal mucosa for the intestine compartment were selected as representative of the EN secretions IE preduodenal and in the intestine, respectively. For the combined estimation, EN flows were based using the average IE of the corresponding gut mucosa and milk casein, the latter taken as representative of proteins exported from their tissue site of synthesis (e.g., digestive enzymes and mucin secretions within the gut; Lapierre et al., 2008).

\section{Statistical Analyses}

For each of the 2 methods (mucosa, combined), results were analyzed using the MIXED procedure of SAS (SAS, 2000). The statistical model included fixed effects of treatment and period and random effect of cow, with the exception of ileocecal data where period effect could not be included in the model because of the limited number of observations (2 cows). The effects of treatments were evaluated using preplanned orthogonal contrasts: hay vs. silages (formic and inoc) and formic vs. inoc. Significance was declared at $P \leq 0.05$ and a trend at $0.05<P<0.10$. The difference between IE (average of d 34 and 35) of rumen biopsy, intestinal biopsy, and milk casein was evaluated using Bonferroni's multiple comparison tests.

\section{RESULTS AND DISCUSSION}

\section{Urea Kinetics}

Total urea production, measured in the 6 cows, increased $(P=0.02$; Table 1$)$ in cows fed inoc compared with those fed formic. The ruminal ammonia contributed predominantly to bacteria $\mathrm{N}(0.81,0.81$, and 0.87 for hay, formic, and inoc, respectively; SEM $=0.07$ ). These proportions were unaffected by treatment but they are at the upper limit of values previously reported (Oldham et al., 1980; Koenig et al., 2000; Hristov et al., 2004). The high values reported in the present study could be partly attributed to efficient capture of ammonia resulting from restricted feeding of a low $\mathrm{N}$ diet at frequent intervals. The contribution of urea to bacteria was also similar among treatment and averaged 0.15 , 0.16 , and 0.15 (SEM = 0.01; Table 1) for hay, formic, and inoc, respectively. These values are similar to the value of 0.19 reported for heifers fed a high forage diet (Marini and Van Amburgh, 2003) but lower than values reported in cows (0.38; Al-Dehneh et al., 1997) or steers (0.30; Wickersham et al., 2009) fed high concentrate diets. The relatively low values reported in the present study can be related to low OM available in the rumen, which has been shown to reduce urea recycling and capture into the rumen (Rémond et al., 1996). In the first estimation of EN (Ouellet et al., 2002), a fixed contribution of urea to bacteria $\mathrm{N}$ of 0.12 , estimated from literature, had been used. A sensitivity analysis had been conducted and indicated that the EN flux at the duodenum could present an error of $12 \%$ if the estimated value deviates from $50 \%$ of the proportion of 0.12 (Zuur et al., 2001). Therefore, a direct measurement of the urea contribution to bacteria, which could differ between treatments, could improve the estimation of EN flows at the duodenum. Urea entry to the gut tended to be greater $(P=0.10$; Table 1$)$ for the inoc treatment. These results are in agreement with the higher ammonia concentration in the rumen fluid reported in cows fed the inoc treatment (Martineau et al., 2007). Urinary urea excretion and the return to the ornithine cycle were larger $(P<0.05$; Table 1$)$ for cows fed inoc compared with those fed formic. These results, similar to those reported for cows supplemented with urea (Lapierre et al., 2004), are in agreement with the reduction in protein solubilization measured when restricting silage fermentation with formic was compared with stimulating fermentation with inoc (Martineau et al., 2006). The lower effective degradability of CP in hay compared with silages (Martineau et al., 2006) did not, however, alter urea kinetics. The utilization of urea for anabolism (UA) was systematically greater than the estimated bacterial flow derived from urea; this difference is even larger when comparing UA and the digested bacteria. This has been reported with bacteria flow estimated indirectly (Marini and Van Amburgh, 2003) or directly (Wickersham et al., 2009), and could be related to uncertainties involved in the estimation of UA obtained by difference. Part of the discrepancy between UA and bacteria derived from urea may relate to the fact that a proportion of the anabolism process can also occur through protozoa growth. Also, absorbed ammonia could be used in transamination reactions and contribute to UA. Although the amount of urea $\mathrm{N}$ losses to feces was not different between treatments, the fractional transfer of the gut entry rate to fecal loss was larger $(P<0.05$; Table 1$)$ when cows were fed hay compared with the silages, probably as a consequence 
Table 1. Effect of forage conservation on the proportion of ruminal ammonia and recycled urea- $\mathrm{N}$ incorporated into the bacteria $\mathrm{N}$ and urea $\mathrm{N}$ metabolism ${ }^{1}$

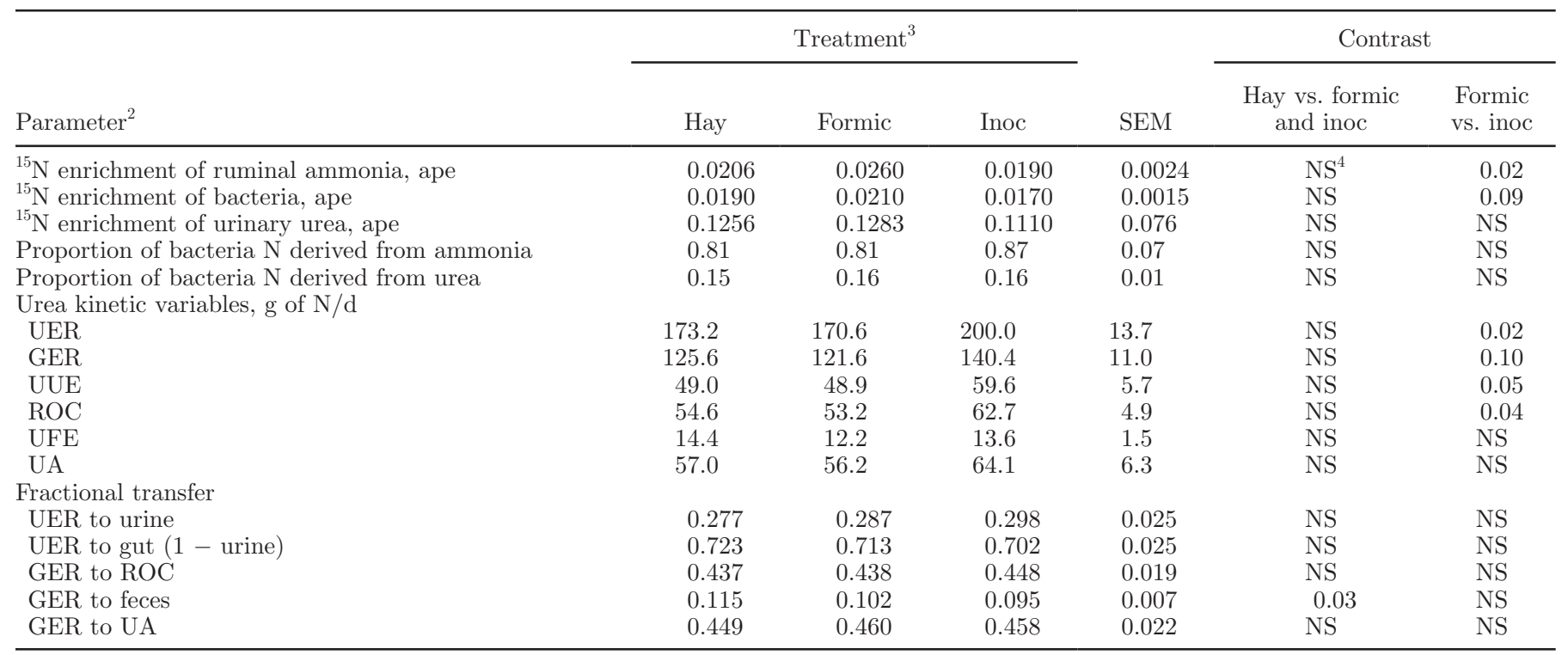

${ }^{1}$ Least squares means and the highest SEM based on $\mathrm{n}=5,6$, and 6 for hay, formic, and inoc, respectively.

${ }^{2}$ ape = atom percent excess (\%); UER = production; GER = entry to gut; UUE = urinary urea excretion; ROC = return to ornithine cycle; $\mathrm{UFE}=$ losses to feces; $\mathrm{UA}=$ reuse for anabolism.

${ }^{3}$ Formic $=85 \%$ formic acid at a rate of $6 \mathrm{~L} / \mathrm{t}$ of fresh forage; inoc $=$ Lactobacillus plantarum LPH-1 and Pediococcus cerevisiae PCH-3 at final application rate of $1.25 \times 10^{5} \mathrm{cfu} / \mathrm{g}$ of fresh forage.

${ }^{4} \mathrm{NS}=P>0.10$

of greater supply of fermentable energy in the form of fiber to the lower digestive tract (Lapierre and Lobley, 2001).

\section{Effect of Forage Conservation Mode on Endogenous N Secretion}

The effect of precursor pool selection will be discussed later. The following section refers to data calculated with the mucosa method when appropriate and based on 4 animals. The $\mathrm{N}$ intake and total $\mathrm{N}$ flow at the duodenum were greater for cows fed silages compared with those fed hay (Table 2). For cows fed hay, duodenal $\mathrm{N}$ flux exceeded $\mathrm{N}$ intake (Table 2), indicating an additional net inflow of $\mathrm{N}$ from urea or $\mathrm{EN}$ or both. In the present study, no differences in urea $\mathrm{N}$ recycled to either the total gut (Table 1) or the forestomach (Table 3 ) were observed between treatments. In contrast, flow of free EN at the duodenum was greater $(P=0.02)$ for cows fed hay. This may be attributed to a greater rate of cell sloughing caused by the longer particles present in hay (Greenwood et al., 1997; Sandek et al., 2001), or by an increase in the contribution of cells and enzyme secretions from the omasal and abomasal compartments (Ørskov et al., 1986; Swanson et al., 2004 ), or both. The proportion of free EN at the duodenum averaged $10 \%$ of total duodenal $\mathrm{N}$, similar to the $13 \%$ reported by Marini et al. (2008) based on a meta-analysis approach. Undigested $\mathrm{N}$ flow from feed sources did not differ $(P>0.10)$ between treatments and represented $28 \%$ of the $\mathrm{N}$ intake (Table 2). The amount of bacterial $\mathrm{N}$ derived from feed tended to be reduced $(P=0.06)$ for cows fed silages, especially with formic treatment. Bacterial $\mathrm{N}$ derived from endogenous and urea was similar between treatments, averaging 23 and $15 \%$, respectively. Interestingly, the contribution of $\mathrm{EN}$ to bacterial $\mathrm{N}$ was greater than that from urea. This may affect ration formulation, especially for those schemes based on AA profiles. Overall, total EN flow at the duodenum (sum of free EN + EN incorporated into bacteria) tended $(P=0.07)$ to be higher in cows fed hay compared with those fed silages but was similar when expressed as proportion of duodenal $\mathrm{N}$ flow, averaging $25.8,23.9$, and $23.9 \%$ of duodenal $\mathrm{N}$ flows for hay, formic, and inoc, respectively. From a metaanalysis, Marini et al. (2008) estimated that 39\% of total $\mathrm{N}$ available in the rumen was derived from $\mathrm{EN}$ sources, including recycled urea. This compares with an average of $42 \%$ across treatments obtained in the present study, based on the sum of EN contribution to the forestomach $(145 \mathrm{~g})$ and urea contribution (urea $\mathrm{N}$ recycled to the forestomach $=57 \mathrm{~g}$ ) relative to the amount of degraded dietary N (279 g/d). A fraction of this overestimation may be attributed to the fact 
Table 2. Flows of $\mathrm{N}$ across the digestive tract estimated using the gut mucosa (mucosa) or the average enrichment of the gut mucosa and milk casein (combined) as representative of the endogenous secretions in cows fed hay, formic acid-treated silage (formic), or inoculated silage $(\text { inoc) })^{1,2}$

\begin{tabular}{|c|c|c|c|c|c|c|c|c|c|}
\hline \multirow[b]{2}{*}{ Parameter, $\mathrm{g}$ of $\mathrm{N} / \mathrm{d}$} & \multicolumn{3}{|c|}{ Mucosa } & \multicolumn{3}{|c|}{ Combined } & \multirow[b]{2}{*}{ SEM } & \multicolumn{2}{|c|}{ Contrast } \\
\hline & Hay & Formic & Inoc & Hay & Formic & Inoc & & $\begin{array}{l}\text { Hay vs. formic } \\
\text { and inoc }\end{array}$ & $\begin{array}{l}\text { Formic } \\
\text { vs. inoc }\end{array}$ \\
\hline Duodenal digesta & 402 & 376 & 410 & 402 & 376 & 410 & 41 & 0.03 & 0.001 \\
\hline Undigested feed & 100 & 113 & 118 & 118 & 128 & 135 & $17(17)$ & NS (NS) & NS (NS) \\
\hline Free endogenous N & 46 & 35 & 40 & 28 & 21 & 22 & $2(2)$ & $0.02(0.02)$ & NS (NS) \\
\hline From endogenous $\mathrm{N}$ & 57 & 52 & 58 & 35 & 31 & 32 & $4(3)$ & NS (NS) & $0.07(\mathrm{NS})$ \\
\hline From urea N & 38 & 37 & 40 & 38 & 37 & 40 & 7 & NS & NS \\
\hline Total endogenous $\mathrm{N}$ in duodenal digesta & 104 & 87 & 97 & 64 & 51 & 55 & $4(4)$ & $0.07(0.04)$ & NS (NS) \\
\hline Feces & 125 & 123 & 135 & 125 & 123 & 135 & 13 & 0.03 & 0.001 \\
\hline Undigested duodenal digesta $^{4}$ & 116 & 112 & 123 & 119 & 116 & 127 & $13(13)$ & NS (NS) & NS (NS) \\
\hline Endogenous N from undigested secretions into intestine & 11 & 10 & 13 & 7 & 6 & 8 & $4(3)$ & NS (NS) & NS (NS) \\
\hline $\begin{array}{l}\text { Endogenous } \mathrm{N} \text { from undigested secretions } \\
\text { into forestomach }\end{array}$ & 31 & 26 & 29 & 19 & 16 & 17 & $2(2)$ & NS (NS) & NS (NS) \\
\hline
\end{tabular}

${ }^{1}$ Least squares means and the highest SEM based on $\mathrm{n}=3,4$, and 4 for hay, formic, and inoc, respectively.

${ }^{2}$ Contrast and SEM are presented as unique value for mucosa and combined methods when identical; if different, combined value is presented in parentheses.

${ }^{3} \mathrm{NS}=P>0.10$.

${ }^{4}$ Undigested duodenal digesta $=$ total fecal $\mathrm{N}-$ endogenous $\mathrm{N}$ from undigested secretions into intestine.

that EN estimates in the current model are from the duodenum, which include EN secretions from omasal and abomasal sources.

Total fecal N loss was greater for cows fed inoc compared with those fed formic $(P=0.001$; Table 2$)$. Fecal $\mathrm{N}$ of endogenous origin, which includes undigested duodenal EN (free and incorporated into bacteria) plus indigested intestinal $\mathrm{EN}$, represented $31 \%$ of total $\mathrm{N}$ excreted, similar to values reported by Larsen et al.
(2001) and Mason (1969) using fecal water-soluble fraction as representative of endogenous origin. Based on our model description, $72 \%$ of the EN loss in feces originated from undigested EN secretions from the forestomach, similar to previous observations with the same model (Ouellet et al., 2002).

Absorption of $\mathrm{N}$ from the forestomach, representing mainly ammonia, tended to increase $(P<0.10)$ for cows fed silages and represented 42,56 , and $53 \%$ of $\mathrm{N}$ intake

Table 3. Secretions, absorptions, and digestibilities of $\mathrm{N}$ across sections of the digestive tract estimated using the gut mucosa (mucosa) or the average enrichment of the gut mucosa and milk casein (combined) as representative of the endogenous secretions in cows fed hay, formic acidtreated silage (formic), or inoculated silage (inoc) $)^{1,2}$

\begin{tabular}{|c|c|c|c|c|c|c|c|c|c|}
\hline \multirow[b]{2}{*}{ Parameter } & \multicolumn{3}{|c|}{ Mucosa } & \multicolumn{3}{|c|}{ Combined } & \multirow[b]{2}{*}{ SEM } & \multicolumn{2}{|c|}{ Contrast } \\
\hline & Hay & Formic & Inoc & Hay & Formic & Inoc & & $\begin{array}{l}\text { Hay vs. formic } \\
\text { and inoc }\end{array}$ & $\begin{array}{l}\text { Formic } \\
\text { vs. inoc }\end{array}$ \\
\hline \multicolumn{10}{|l|}{ Secretions, $g$ of N/d } \\
\hline Urea $\mathrm{N}$ into forestomach & 52 & 59 & 60 & 44 & 52 & 52 & $8(7)$ & $\mathrm{NS}^{3}(\mathrm{NS})$ & NS (NS) \\
\hline Endogenous $\mathrm{N}$ into forestomach & 142 & 143 & 147 & 75 & 73 & 72 & $9(5)$ & $\mathrm{NS}(\mathrm{NS})$ & NS (NS) \\
\hline Endogenous $\mathrm{N}$ into intestine & 40 & 34 & 42 & 24 & 21 & 24 & $13(7)$ & NS (NS) & NS (NS) \\
\hline Intestine & 313 & 288 & 316 & 299 & 275 & 299 & $36(33)$ & NS $(0.10)$ & NS (0.03) \\
\hline \multicolumn{10}{|l|}{ Real digestibility, \% } \\
\hline Forestomach & 26 & 39 & 34 & 14 & 30 & 23 & $4(4)$ & $0.09(0.06)$ & NS (NS) \\
\hline Intestine & 71 & 70 & 70 & 70 & 69 & 69 & $1(1)$ & NS (NS) & NS (NS) \\
\hline Whole tract & 78 & 82 & 80 & 74 & 78 & 76 & $1(1)$ & NS $(0.06)$ & NS (NS) \\
\hline
\end{tabular}

${ }^{1}$ Least squares means and the highest SEM based on $\mathrm{n}=3,4$, and 4 for hay, formic, and inoculated, respectively.

${ }^{2}$ Contrast and SEM are presented as unique value for mucosa and combined methods when identical; if different, combined value is presented in parentheses.

${ }^{3} \mathrm{NS}=P>0.10$. 
Table 4. Flows of $\mathrm{N}(\mathrm{g} / \mathrm{d})$ at the ileocecal area estimated using the gut mucosa (mucosa) or the average enrichment of the gut mucosa and milk casein (combined) as representative of the endogenous secretions in cows fed hay, formic acid-treated silage (formic), or inoculated silage $(\text { inoc })^{1,2}$

\begin{tabular}{|c|c|c|c|c|c|c|c|c|c|}
\hline \multirow[b]{2}{*}{ Parameter, $g$ of $\mathrm{N} / \mathrm{d}$} & \multicolumn{3}{|c|}{ Mucosa } & \multicolumn{3}{|c|}{ Combined } & \multirow[b]{2}{*}{ SEM } & \multicolumn{2}{|c|}{ Contrast } \\
\hline & Hay & Formic & Inoc & Hay & Formic & Inoc & & $\begin{array}{l}\text { Hay vs. } \\
\text { formic and inoc }\end{array}$ & $\begin{array}{l}\text { Formic } \\
\text { vs. inoc }\end{array}$ \\
\hline Undigested duodenal digesta $^{4}$ & 102 & 139 & 133 & 107 & 143 & 140 & $27(26)$ & NS $(0.09)$ & NS (NS) \\
\hline Endogenous $\mathrm{N}$ from undigested secretions into intestine & 13 & 10 & 18 & 8 & 6 & 11 & $7(5)$ & NS (NS) & NS (NS) \\
\hline $\begin{array}{l}\text { Endogenous } \mathrm{N} \text { from undigested secretions } \\
\text { into forestomach }\end{array}$ & 23 & 30 & 31 & 14 & 18 & 19 & $3(2)$ & NS (NS) & NS (NS) \\
\hline
\end{tabular}

${ }^{1}$ Least squares means and the highest SEM based on $\mathrm{n}=2,2$, and 2 for hay, formic, and inoculated, respectively.

${ }^{2}$ Contrast and SEM are presented as unique value for mucosa and combined when identical; if different combined values are presented in parenthesis.

${ }^{3} \mathrm{NS}=P>0.10$.

${ }^{4}$ Undigested duodenal digesta $=$ total ileal $\mathrm{N}-$ endogenous $\mathrm{N}$ from undigested secretions into intestine.

for hay, formic, and inoc, respectively (Table 3). These proportions are similar to estimates obtained in sheep fed diets that exceeded $\mathrm{N}$ requirement for microbial protein synthesis (Hettiarachchi et al., 1999). The current results also agree with those of Parker et al. (1995), who reported that $50 \%$ of $\mathrm{N}$ intake enters the rumen irreversible loss of ammonia pool. The real digestibility of $\mathrm{N}$ in the forestomach tended to be higher $(P=0.09)$ for cows fed silages (37\%) than for those fed hay $(26 \%)$, reflecting the rapidly degradable $\mathrm{N}$ content of silages compared with hay (Martineau et al., 2007).

Endogenous $\mathrm{N}$ flows at the ileum could be only estimated for the 2 cows with an ileal cannula. Total N flow at the ileum was higher $(P<0.001)$ when cows were fed the silages rather than hay (Table 4 ). For the cows fed inoc, this is probably because of the higher return of urea to the gastrointestinal tract. The reason is less clear for cows fed formic, although undigested feed at the duodenum was numerically greater and $\mathrm{N}$ absorption between the duodenum and the feces was numerically lower. The ileal EN flow was unaffected by treatment and represented, on average, $31 \%$ of ileal $\mathrm{N}$ flow. This value yields an average true small intestinal $\mathrm{N}$ digestibility for the combination of undigested feed, bacteria, and EN of $69 \%$, similar to the 65 to $70 \%$ reported by Larsen et al. (2001) using 2 different approaches (the difference method and the AA profile method).

Together, these results illustrate that forage type can alter both free EN and total EN at the duodenum. In addition, contribution of EN to bacteria $\mathrm{N}$ can be more important than urea utilization. Indeed, the EN incorporated into bacteria is of similar magnitude to free EN flow at the duodenum. Approximately $30 \%$ of fecal $\mathrm{N}$ was as $\mathrm{EN}$, of which $70 \%$ originates from the forestomach. The limited data from ileal EN flux sup- port the conclusions based on fecal samples. Overall, these data clearly indicate the importance of including EN at the duodenum, both as free and incorporated into bacteria, to estimate with better accuracy the true net $\mathrm{N}$ supply to cows.

\section{Limitations of Current Methodologies and Implications for Predictive Models}

Precursor Pool. The uncertainty of the correct precursor pool(s) that represent the site of EN production is a major limitation to isotope-based techniques. Pancreatic tissue, gastric or intestinal mucosa, the TCA-soluble fraction of portal vein plasma (Hess et al., 1998), mucins (Lien et al., 1997; Leterme et al., 1998), or other export proteins directly linked to EN, such as pancreatic or bile juice (Souffrant et al., 1993), have been proposed.

In the current experiment, the IE of biopsies from the rumen and duodenal mucosa and milk casein differed $(P<0.05)$ and averaged $0.3944,0.4013$, and 0.4327 \pm 0.0023 atom percent, respectively. These values are similar to those reported earlier (Ouellet et al., 2002). Combining the IE of mucosa and milk casein reduced the variation of EN estimations but affected only a few treatment differences compared with the use of mucosal IE as the precursor. Therefore, qualitative treatment responses in EN were independent of precursor selection, although the absolute values were higher for the mucosal method. For example, the average secretion of EN into the forestomach and the intestine were lowered by 41 and $49 \%$, respectively (Table 2), for the combined method compared with the mucosal method. Similarly, average absorption was reduced by 41 and $5 \%$ at the forestomach and postduodenal sites, respectively, when comparing the combined method with the 
mucosa method (Table 3), whereas real digestibility in the forestomach was also reduced by $46 \%$ for hay and $26 \%$ for silages. These examples emphasize the effect of precursor pool selection, especially when the absolute contribution of EN is the objective. Regrettably, an ideal sample, technically easy to obtain and representative of the precursor pool, does not currently exist. However, because of the concordance observed between values published in the literature and the present study, the rumen mucosa seems appropriate to evaluate EN, at least at the duodenum. Given the low number of results accumulated until now, the use of the mucosal tissue in the calculation of EN flow at the ileum remains to be evaluated.

Implications for Predictive Models. This project is part of a wider initiative to develop quantitative estimation of EN flows in dairy cows. This necessitates assessment of the current estimates against reported values obtained by other approaches to assess the validity of the model.

Of the total duodenal N, free EN plus EN incorporated in bacterial $\mathrm{N}$ contributed 26,23 , and $24 \%$ for hay, formic, and inoc, respectively (Table 2). These values are higher than the $15 \%$ reported previously using the same approaches (Ouellet et al., 2002) and can be explained by a larger contribution of EN to bacteria biomass $(58 \%$ in the present project vs. $48 \%$ in Ouellet et al., 2002). Based on a simulated conventional dairy ration, Marini et al. (2008) estimated that EN contributed $35 \%$ to the duodenal flow, but this value included the contribution of urea to bacteria protein synthesis. Inclusion of this fraction within the current study raises the EN contribution to $34 \%$ of duodenal flow (mucosa method). With a DMI of $17.5 \mathrm{~kg} / \mathrm{d}$, the measured EN at the duodenum corresponded to $5.5 \mathrm{~g}$ of $\mathrm{N} / \mathrm{kg}$ of DMI, almost 3-fold the value estimated with the NRC (2001) model. Interestingly, the free EN measured (2.3 $\mathrm{g}$ of $\mathrm{N} / \mathrm{kg}$ of DMI) is similar to the $1.9 \mathrm{~g}$ of $\mathrm{N} / \mathrm{kg}$ of DMI estimated for EN by the NRC (2001) model. Our model distinguishes between the sources of $\mathrm{N}$ used for microbial growth and shows EN as an important source for bacterial N; as such, this affects AA requirements and, if unaccounted, could lead to an overestimate of true supply.

The EN fecal losses provide a direct estimation of metabolic fecal protein (MFP). The NRC (2001) model estimates MP requirement for MFP as DMI $\times 30 \mathrm{~g} / \mathrm{d}$ (Swanson, 1977) minus estimated undigested bacteria. For cows consuming $17.5 \mathrm{~kg}$ of $\mathrm{DM} / \mathrm{d}$ with an average duodenal flow of bacteria of $246 \mathrm{~g}$ of N/d, MP requirement for MFP according to NRC (2001) equals $393 \mathrm{~g}$ of $\mathrm{MP} / \mathrm{d}$. In the current study, fecal EN losses, calculated using either the mucosa or combined method, yields
40 and $24 \mathrm{~g} / \mathrm{d}$, respectively. Even the highest value that equates to $250 \mathrm{~g}$ of protein/d is lower than the estimated $393 \mathrm{~g}$ of MP/d (NRC, 2001). Nonetheless, as stated by Swanson (1982), "whichever portion of the fecal $\mathrm{N}$ is designated MFP, it is converted to maintenance requirement for protein only when modified by appropriate factors for utilization efficiency of feed protein." When an average efficiency factor of 0.67 (NRC, 2001) is applied, the estimated MFP are raised to $373 \mathrm{~g}$ of $\mathrm{MP} / \mathrm{d}$. In a meta-analysis using the Lucas principle, Marini et al. (2008) obtained an MFP of $3.96 \mathrm{~g}$ of N/ $\mathrm{kg}$ of DM equivalent to $68 \mathrm{~g}$ of fecal $\mathrm{EN} / \mathrm{d}$ if applied to our cows, also higher than our maximal estimation of $40 \mathrm{~g} / \mathrm{d}$. These overestimations compared with value obtained in the present study could be related to the fact that both the NRC (2001) and Marini et al. (2008) models include urea $\mathrm{N}$ contribution to MFP.

\section{CONCLUSIONS}

The results of this study demonstrate that feeding hay compared with silages increased free EN flow at the duodenum but had no effect on ileal or fecal EN flows. This study showed the important contribution of EN to bacteria $\mathrm{N}$ flowing at the duodenum as well as free endogenous and urea input to duodenal flux. The model also indicated that approximately one-third of the total $\mathrm{N}$ flowing out of the ileal or fecal segment was of EN origin. In the current model, the MFP do not include urea, which differs from the NRC (2001) model. Although the MFP losses estimated using the NRC (2001) model are close to estimates obtained with the current model, when the latter was adjusted for an efficiency factor, the effect of diet composition, variation of $\mathrm{N}$ efficiency, and detail about AA composition would be better investigated using the ${ }^{15} \mathrm{~N}$ dilution technique.

\section{ACKNOWLEDGMENTS}

The authors gratefully thank M. Pelletier, M. Léonard, and S. Provencher at the Dairy and Swine Research Centre in Sherbrooke for their technical assistance. The statistical advice of S. Méthot (Dairy and Swine Research Centre in Sherbrooke) and the surgical expertise of P. Dubreuil and M. Babkine (Faculté de Médicine Vétérinaire, Université de Montréal, St-Hyacinthe) are also gratefully acknowledged, as is the mass spectrometry expertise of E. Milne (Rowett Institute of Nutrition and Health, Aberdeen, UK). The authors thank the staff of the Dairy Centre for care of the animals. Appreciation is extended to La Fédération des Producteurs de lait du Québec and Agriculture 
and Agri-Food Canada for their financial support. This study was also supported by the Scottish Government via funding provided by the Rural and Environment Research and Analysis Directorate to the Rowett Institute of Nutrition and Health, University of Aberdeen, and to Biomathematics and Statistics Scotland.

\section{REFERENCES}

Al-Dehneh, A., J. T. Huber, R. Wanderley, C. B. Theurer, M. Pessarakli, and D. DeYoung. 1997. Incorporation of recycled urea-N into ruminal bacteria flowing to the small intestine of dairy cows fed a high-grain or high-forage diet. Anim. Feed Sci. Technol. 68:327-338.

AOAC. 1990. Official Methods of Analysis. Vol. 1 and 2. 15th ed. AOAC, Arlington, VA.

Canadian Council on Animal Care. 1993. Guide to Care and Use of Experimental Animals. Vol. 1. 2nd ed. E. D. Offert, B. M. Cross, and A. A. McWilliam, ed. Can. Counc. Anim. Care, Ottawa, Ontario, Canada.

Greenwood, R. H., J. L. Morrill, E. C. Titgemeyer, and G. A. Kennedy. 1997. A new method of measuring diet abrasion and its effect on the development of the forestomach. J. Dairy Sci. 80:2534-2541.

Hess, V., J. N. Thibault, and B. Sève. 1998. The ${ }^{15} \mathrm{~N}$ amino acid dilution method allows the determination of the real digestibility and of the ileal endogenous losses of the respective amino acid in pigs. J. Nutr. 128:1969-1977.

Hettiarachchi, M., R. M. Dixon, and J. V. Nolan. 1999. Effect of intraruminal urea infusions and changing digestible organic intake on nitrogen kinetics in sheep fed rice straw. J. Agric. Sci. 133:109121.

Hristov, A. N., R. P. Etter, J. K. Ropp, and K. L. Grandeen. 2004. Effect of dietary crude protein level and degradability on ruminal fermentation and nitrogen utilization in lactating dairy cows. J. Anim. Sci. 82:3219-3229.

INRAtion. 2004. V3.2. Logiciel de Rationnement des Ruminants. J. Agabriel, P. Champciaux, and C. Espinasse, ed. CNERTA, Dijon, France.

Jansman, A. J. M., W. Smink, P. van Leeuwen, and M. Rademacher. 2002. Evaluation through literature data of the amount and amino acid composition of basal endogenous crude protein at the terminal ileum of pigs. Anim. Feed Sci. Technol. 98:49-60.

Kennedy, P. M., and L. P. Milligan. 1980. Input of endogenous protein into the forestornach of sheep. Can. J. Anim. Sci. 60:1029-1032.

Koenig, K. M., C. J. Newbold, F. M. McIntosh, and L. M. Rode. 2000 Effects of protozoa on bacterial nitrogen recycling in the rumen. J. Anim. Sci. 78:2431-2445.

Lapierre, H., and G. E. Lobley. 2001. Nitrogen recycling in the ruminant: A review. J. Dairy Sci. 84(E Suppl.):E223-E236.

Lapierre, H., D. R. Ouellet, R. Berthiaume, C. Girard, P. Dubreuil, M. Babkine, and G. E. Lobley. 2004. Effect of urea supplementation on urea kinetics and splanchnic flux of amino acids in dairy cows. J. Anim. Feed Sci. 13:319-322.

Lapierre, H., D. R. Ouellet, R. Berthlaume, R. Martineau, G. Holtrop and G. E. Lobley. 2008. Distribution of ${ }^{15} \mathrm{~N}$ in amino acids during ${ }^{15} \mathrm{~N}$-leucine infusion: Impact on the estimation of endogenous flows in dairy cows. J. Dairy Sci. 91:2702-2714.

Larsen, M., T. G. Madsen, M. R. Weisbjerg, T. Hvelplund, and J. Madsen. 2000. Endogenous amino acid flow in the duodenum of dairy cows. Acta Agric. Scand. Sec. Anim. Sci. 50:161-173.

Larsen, M., T. G. Madsen, M. R. Weisbjerg, T. Hvelplund, and J. Madsen. 2001. Small intestinal digestibility of microbial and endogenous amino acids in dairy cows. J. Anim. Physiol. Anim. Nutr. (Berl.) 85:9-21.

Legay-Carmier, F., and D. Bauchart. 1989. Distribution of bacteria in the rumen contents of dairy cows given a diet supplemented with soya-bean oil. Br. J. Nutr. 61:725-740.
Leterme, P., A. Théwis, and B. Sève. 1998. The current ${ }^{15} \mathrm{~N}$-leucine infusion technique is not suitable for quantitative measurements of ileal endogenous amino acid flows in pigs. J. Nutr. 128:19611968.

Lien, K. A., W. C. Sauer, and M. E. Dugan. 1997. Evaluation of the $15 \mathrm{~N}$-isotope dilution technique for determining the recovery of endogenous protein in ileal digesta of pigs: Effect of the pattern of blood sampling, precursor pools, and isotope dilution technique. J. Anim. Sci. 75:159-169.

Lobley, G. E., D. M. Bremner, and G. Zuur. 2000. Effects of diet quality on urea fates in sheep as assessed by refined, non-invasive $\left[{ }^{15} \mathrm{~N}^{15} \mathrm{~N}\right]$ urea kinetics. Br. J. Nutr. 84:459-468.

Marini, J. C., D. G. Fox, and M. R. Murphy. 2008. Nitrogen transactions along the gastrointestinal tract of cattle: A metaanalytical approach. J. Anim. Sci. 86:660-679.

Marini, J. C., and M. E. Van Amburgh. 2003. Nitrogen metabolism and recycling in Holstein heifers. J. Anim. Sci. 81:545-552.

Martineau, R., H. Lapierre, D. R. Ouellet, D. Pellerin, and R. Berthiaume. 2006. In situ degradation of timothy conserved as restrictively or extensively fermented silage or as hay. Can. J. Anim. Sci. 86:299-306.

Martineau, R., H. Lapierre, D. R. Ouellet, D. Pellerin, and R. Berthiaume. 2007. Effects of the method of conservation of timothy on nitrogen metabolism in lactating dairy cows. J. Dairy Sci. 90:2870-2882

Mason, V. 1969. Some observations on the distribution and origin of nitrogen in sheep feces. J. Agric. Sci. 73:99-111.

McDonald, P., N. Henderson, and S. Heron. 1991. The Biochemistry of Silage. 2nd ed. Chalcombe Publications, Marlow, UK.

Nagel, S. A., and G. A. Broderick. 1992. Effect of formic acid or formaldehyde treatment of alfalfa silage on nutrient utilization by dairy cows. J. Dairy Sci. 75:140-154.

NRC. 2001. Nutrient Requirements of Dairy Cattle. 7th ed. Natl. Acad. Press, Washington, DC.

Oldham, J. D., I. Bruckental, and A. Nissenbaum. 1980. Observations on rumen ammonia metabolism in lactating dairy cows. J. Agric. Sci. 95:235-238.

Ørskov, E. R., N. A. MacLeod, and D. J. Kyle. 1986. Flow of nitrogen from the rumen and abomasum in cattle and sheep given proteinfree nutrients by intragastric infusion. Br. J. Nutr. 56:241-248.

Ouellet, D. R., M. Demers, G. Zuur, G. E. Lobley, J. R. Seoane, J. V. Nolan, and H. Lapierre. 2002. Effect of dietary fiber on endogenous nitrogen flows in lactating dairy cows. J. Dairy Sci. 85:3013-3025.

Parker, D. S., M. A. Lomax, C. J. Seal, and J. C. Wilton. 1995. Metabolic implications of ammonia production in the ruminant. Proc. Nutr. Soc. 54:549-563.

Rémond, D., F. Meschy, and R. Boivin. 1996. Metabolites, water and mineral exchanges across the rumen wall: Mechanisms and regulation. Ann. Zootech. 45:97-119.

Sandek, A., K. Krawielitzki, J. Kowalczyk, F. Kreienbring, U. Schonhusen, M. Gabel, T. Zebrowska, H. Hagemeister, and J. Voigt. 2001. Studies on N-metabolism in different gastrointestinal secretions of sheep using the digesta exchange technique. 2. Passage of endogenous nitrogen. J. Anim. Feed Sci. 10:605-618.

Sarraseca, A., E. Milne, M. J. Metcalf, and G. E. Lobley. 1998. Urea recycling in sheep: Effects of intake. Br. J. Nutr. 79:79-88.

SAS. 2000. SAS Institute. SAS/STAT User's Guide. Release 8.02. SAS Inst. Inc., Cary, NC.

Siddons, R. C., J. V. Nolan, D. E. Beever, and J. C. MacRae. 1985. Nitrogen digestion and metabolism in sheep consuming diets containing contrasting forms and levels of N. Br. J. Nutr. 454:175-187.

Souffrant, W. B., A. Rérat, J. P. Laplace, B. Darcy-Vrillon, R. Köhler, T. Corring, G. Gebhardt, F. Bernard, M. L. Jähnichen, B. Schneider, and F. Cointepas. 1993. Exogenous and endogenous contributions to nitrogen fluxes in the digestive tract of pigs fed a casein diet. III. Recycling of endogenous nitrogen. Reprod. Nutr. Dev. 33:373-382. 
Swanson, E. W. 1977. Factors for computing requirements of protein for maintenance of cattle. J. Dairy Sci. 60:1583-1593.

Swanson, E. W. 1982. Estimation of metabolic protein requirements to cover unavoidable losses of endogenous nitrogen in maintenance of cattle. Pages 183-197 in Protein Requirements of Cattle: Symposium. F. N. Owens, ed. Oklahoma State University, Stillwater.

Swanson, K. C., J. A. Benson, J. C. Matthews, and D. L. Harmon. 2004. Pancreatic exocrine secretion and plasma concentration of some gastrointestinal hormones in response to abomasal infusion of starch hydrolyzate and/or casein. J. Anim. Sci. 82:1781-1787.
Wickersham, T. A., E. C. Titgemeyer, and R. C. Cochran. 2009. Methodology for concurrent determination of urea kinetics and the capture of recycled urea nitrogen by ruminal microbes in cattle. Animal 3:372-379.

Zuur, G., D. R. Ouellet, H. Lapierre, and G. E. Lobley. 2001. A model for estimating endogenous nitrogen losses across the rumen. Abstracts of communications, Proc. 33rd Mtg. Agric. Res. Modelers' Group. J. Agric. Sci. (Camb.) 137:117-118. 